\section{Globalization and Culture Hybridity; The Commodification on Korean Music and its Successful World Expansion}

\author{
Muhammad Fithratullah \\ American Studies Graduate Program. Faculty of Cultural Sciences, Universitas Gadjah \\ Mada. Indonesia \\ e-mail: fithratullahmuhammad@yahoo.com
}

\begin{abstract}
The absence of borders increases the consciousness on the larger access which creates global dependency in many ways such as trades, traveling, tourism, and culture information and creates borderless countries. Lyman (2000) explains that the movement and the influence of globalization are triggered by many factors such as the economic expansion in the form of massive industrialization and the development of science, technology, and communication. The beauty of globalization is the ability to force people to be creative and innovative in creating something beneficial. Culture are wrapped and formed then exposed, which later called as "exporting culture" or in the more popular form, it is called as commodification. The boom of Korean popular culture in all over Asian countries has increased starting in 2000 it moves forward to rule all over Asia (Hyejung: 2007). The rise of Korean Popular culture through globalization triggers a favorable environment to the new commodities allowing interaction between nations. K-Pop Global expansion is through three stages "Competence" or Hard Power, "Attraction" or Soft Power and last but not least Criticism in order to be able to continue or to have a sustainable career in global industries many things should be taken including "facelift". The purpose of this research is to figure out that commodification on culture is the answer for Korean Music to have successful world expansion and global stage powered with qualitative research is applies in this research.
\end{abstract}

\section{Keywords}

Globalization, Commodification, Korean Wave, Cultural Hybridity

\section{Introduction}

\subsection{Background of Study}

Citation: Fithratullah, M: Globalization and Culture Hybridity: The Commodification on Korean Music and its Successful World Expansion. In. D. Ekawati, et al (eds.): Proceeding of The American Studies International Conference 2018, Vol. 2, pp. 83-89 UGM Digital Press Social Sciences and Humanities, Yogyakarta (2019).

Published: May. 2019
The increasing awareness on borderless society and openness access triggers more dependency among one people in a particular society to another is one of the crucial impacts of the globalization. Trading, tourism, traveling, tradition and culture, information, rapid finally erase the existence of country borders and create limitless society (Giddens, 1990). Globalization can be understood as a social process whereas the geographical borders, social condition, culture diversity and finally personal awareness on limitation are put aside. (Waters, 1995). Globalization could be understood as a process technological development, and interaction becoming the force to 
conducted individually or as a nation which interacts, depend and influence each other then it mixes all together and formed new culture or hybrids culture. (Albrow, 1990).

Tomlinson in 1999 argues that globalization is the shrink of geographical distance, time efficiency, and also the massive movement of products or goods, services, cultures or even ideas through information and technology such as electronic media. Globalization creates new society whom aware to the free access, the society whom easier to influence and to be inspired and the society who forced to be more creative and innovative to win a global scale market. Globalization is always correlated with economic activity as a form of markets expansion, globalization has to force human resources to have more competence and skills in order to be brilliant in presenting new ideas, even to reshape anything into a product which later known as commodification includes ideas or any intellectuals' things and creates massive benefits. It would be unfair if globalization judged as results of economic factors, but also to the factors that force the economic expansion such as rapid development of technology, information, and communication. (Lyman, 2000). The openness or borderless society then will be understood as a society whom aware to the free access in gaining more information to do exchange culture and also time efficiency whereas the access to move one people or products from places to places is becoming easier and the possibilities of culture and some other random culture to be mix into a new culture or hybrid culture is higher.

One of the beauties of globalization is the ability to force people to be more creative and innovative in creating something and create anything possible as a product that could be beneficial. One of them is culture, culture is wrapped and formed in such a way then exposed, which later called as "exporting culture" or in the more popular form it is called as commodification. There are a lot of definitions of culture, Bourdieu and Thompson (1991) argue regarding culture and society which considered as a mechanism of relation it is functioned to show the social diversity; whereas every action within the society considered the culture and could be socially interpreted, itbrings such a broad meaning of culture. the other believe that it is used to positioned themselves with regards to the person or group intention in order to make a difference with others, somehow closed considered to identity. (Tomlinson, 1999; Dunn, 2008).

Hybridity as a characteristic of culture is considered suitable and in line with globalization due to its variety existence, hybridity somehow foretold traces of other cultures is a part of other culture, offering foreign media and transcultural marketers to have an effective relationship between their commodities and the local commodities. As an intercultural discourse, hybridity served an active exchange that leads to the mutual development of both local and foreign. (Kraidy, 2005). In the relation of commodification, hybridity somehow having the same concept, the ideas of changing and merging or transforming one culture to other or making a new acceptable based on the adjustment so that it could be accepted is sound very commodification. In order for a product or a culture could be accepted by other culture some transformation and merger needed to be conducted in order to create commodities which welcome benefits.

Commodification appears as a result of Globalization and market expansion, culture nowadays considered to be a commodity; something that could be sold and export even could attract more people to come and creating more benefits especially in a nowadays global society. Every aspect of culture whether it is goods, product, services or even something intangible like tradition and customs could be wrapped into commodity and close related to consumerism. The commodification considered bias both positive and negative, it is considered to be a successful commodity and being exposed and exploited and blindly commercialize but yet commodification of culture comes as a way out to save culture from extinction. (Proschell, 2012). Throsby (2005) argues that maintaining culture must start from the original place where it all begins, and the commercial side must not disturb the elements of culture. Hence interdependencies among both of them have created a complex relationship between culture and commerce.

In the new millennia, the world introduced to a new culture which grew so fast from the east, called Korean Popular culture, K-Pop or Korean Wave. Since 2000's Korean wave has wiped the world starting from East Asia to South East Asia moving to South Asia and Australia follows by the Pacific and the whole world now, with several products like films, serial drama, foods, fashion, and music. In Indonesia in examples Korean Popular culture is more popular than our own popular culture, one of the most famous of all is the Korean Music. K-Pop becominga phenomenon in the world hand in hands with the rapid development of technology and information such as the growing number of Android cellphone has triggered the popularity of K-Pop. Globalization and commodification becoming the challenge for other culture to survive but for Korea, it is now useful to preserve their culture through commodification and adjustment with today value so that it is accepted by the major population of the world and save from 
extinction yet to introduce their identity and culture to the rest of the world. numbers of K-Pop global phenomenon such as Psy, Big Bang, Wonder Girls, Super Junior, 2pm, Jay Park, Exo, BTS, iKon and also Black Pink in Global Music industry shown how commodification and Culture Hybridity somehow becoming receipt for global expansion. This paper will focus on Korean Music and how it is uniquely wrapped, adjusted and commodified in order to be saved from extinction yet to conquer the world stage and the qualitative methods are applied.

\subsection{Research Question}

Due to the background above about globalization, culture and culture hybridity and commodification as a means to conquer the world stage or world expansion for the local industry, the writer finally formulates the research question as:

How the commodification on Korean Music becoming the answer for its successful global expansion?

\subsection{Purpose of the Study}

Coherence with the research questions the purpose of this research is to figure out that commodification on culture is the answer for Korean Music to have successful world expansion and global stage.

\section{Theoretical Framework}

In exploring the ideas of globalization which change and transformed culture into commodities for larger scale markets, the use of commodification as theory is urgent.

\subsection{Theory of Commodification}

Theory of commodification focuses on anything which can be transformed into commodities as a media and also a source of capitalism and its expansion. (Mosco, 2009). Ideas related to industries rapidly develop and greatly contribute to the economic and political development of a nation. Commodification also relates to the process of creating a product from the values existed in the society, and these values are changing, reshape and transformed into commercial products which could be beneficial to certain industries. According to Baudrillard (1981), each of commodities is a part of a social system and has its own particular sign value, "commodities are no longer defined by their use but rather by what they signify." (p. 7)It can be understood that commodities are a part of culture coherence with to cultural studies which considered any commodity could become culture as long as it contains meaning and part of subjects lived experience. (Dunn, 2008).

Commodification is a complex structure, due to its production which is needed to be accordance with the society and people needs or creating a new paradigm in the midst of the society by serving new values in accordance with what the industry needs. As a complex structure commodification also considered as an abstract connection of social, cultural and even temporal influence. In order to create an efficient promotion of commodity, a common social context between the producer and consumer must be in the level of adequate knowledge of the shopper and in the other hand exchangeability of particular environment is given. (Proschel, 2012). Commodification will be considered effective when it meets the needs of the society, it is urgent that a commodity to be consumed, the activity of consuming the commodities is considered as the simple routine of buying product or goods according to their purpose. Consumption constitutes huge ideas of culture as it is express values and social meaning of the commodities itself. (Douglas \& Isherwood, 1996; Dunn, 2008). To be understood that commodities could be considered as a culture when it is consumed by the consumer and when it successfully presents meaningful values to the society itself.

The close relation between Culture and commercial somehow creates a domino effect culture as the capital of commodities being blindly exploited but on the other hand, it is considered the way to preserve culture. the main ideas of commodification are a commodity and the driving force is the industries, this industry will focus on how something is created based on the needs of the society and on how later it will create benefits for the industries and massively consumed by the people as their primary needs. (Mosco, 2009). 
The central point of Commodification of containing is spatialization whereas taking a function to connect the world without geographical matters. Spatialization becoming importance due to the industries is in need to share their products to the world for profits. Spatialization and commodification having the same elements make them easier to be capitalized, both depend on the markets which formed by the society needs to be correlated to particular themes close enough to the environment of the society. (Mosco, 2009). In accordance to above explanations, it is clear that within music industries spatialization has taken over its function, spatialization or commodification of contains certain product or commodities are needed to be well accepted locally, nationally and globally then it is becoming important for industries to follow the favors of the society and markets. The increasing of capitalization of contains over by the producer it is not difficult to produce, what actually needed by the producer is a seat, silent and watch the movement of taste, favors, and motive shows by the society. Because the global society demands to become an important aspect for the continuity of the industries especially in order to create massive profits globally and give a mutual effect to growing of the industries.

\subsection{Transnationalism}

Global culture is emerging and it's starting to become a debate related to its origin, structure, and contents which is considered very American. American might be not the only player in the world especially in the global cultural arena but America Transnationalizing culture is still expected to be the main player and the most dominant in the near future (Berger, 2002). Transnationalism ideas refer to the diffusion and the extension of social, political and economic processes beyond the country borders. The international mechanism is taken by the non-government bodies and international organization. (Robinson, 1998) the shifting ideas of the definition of states and social structure becoming transnationalized. Robinson (1998) argued that the major topics of Transnational studies related to economic globalization, the transnationalization of state, classes, political processes, culture and current integration processes which took place around the globe through a formal and international organization.

Transnationalism somehow creates a greater connection between individual, communities, and societies across borders, bringing about changes in the social, cultural, economic and political perspectives of the society of the origin and destination. It is not a new process, of course; local cultures have long been influenced and shaped by outside forces, and, historically, have become detached from their local anchoring under capitalism. The current phase of globalization differs from the past because of the dramatically increased transnational movement of material foods, images, and people, which leads to new mixtures of culture or hybridization. Transnational capitalism's division of labor and free trade produce multi-variegated fusions, blurred borders, cultural "homelessness" as well as cosmopolitanism. Its worldwide infrastructure of airports, malls, computer terminals, chain restaurants, and other "nonplaces" erase distinct space and history, whereas its basic means of communication, the Internet, is even more radically deterritorialized (Tomlinson, 1999) Cultural goods with indefinite origins abound; what appears to be traditional, on closer inspection is invented, and what seems to be homogeneous, is hybrid. "American" and various other "nationally" made products often entail design and engineering ideas, parts, and labor from many nations, which makes it hard to specify a country of origin. Seeing the ideas of how globalization and transnationalism are connected to each other as a threat to the local culture I believe that the Transnationalism will be the best approach to be the hands in analyzing the topics.

\section{Methods}

The writer used the qualitative methods in this research, this methods is a rewarding activity due to its abilities to engage with many aspects, its dimension is believable to have a wide range of dimension of the social world, including the motif, texture of everyday life, the understanding, experiences, and imagination of our research participants, the ways that social processes, institutions, discourses, or even work relationship and the significance of the meaning that they convey. This methodology believed to celebrate the richness, depth, nuance, context multi-dimensionality and complexity rather than being inconvenienced by them. (Mason, 2002). Qualitative research directly focuses on analyses and explanations. It means that it has more capacity to explains how things work in a particular context. Qualitative strength is on its ability to connect context with explanation, it means that qualitative research is capable to produce an excellent cross-contextual generality. This research involves the use of 
qualitative data such as; interviews, documents, and observation in order to be able to comprehend the social phenomenon. Qualitative research methods originally from social sciences the purpose is to support the researcher to study social and cultural oriented phenomena. (Mason, 2002). Denzin and Lincoln (1994) argue that qualitative research focuses on the interpretation of phenomena in their natural settings to make sense in terms of the meanings people bring to these settings.

\section{Results and Discussion}

\subsection{The Rise of Korean Popular Culture and its Success}

Hallyu or Korean wave in Mandarin means "The wind that blows strong to China Man land" in other words Chinese society called it as Hanmito describes its fanatic followers of K-Pop in China also have the meaning as "the Lost Children" describing how fanatic Chinese society is to K-Pop. (Rae, 2005). Chinese perspective is somehow contrasted and against K-Pop or Korean waves, they considered it ruining the Chinese culture. It is something that cannot be denied that the rapid development of K-Pop is starting in East Asia (Korea Peninsula, Japan, China and Taiwan). It is stated that the founder of what is "west" and "east" is the west this idea polarizes as a main agent of phenomena from the perspective of world history. Each of the polar is influence each other and creating change. The changing regional orders in East Asia are divided into four stages: pax-Mongolica - Sino Centric - World Eurocentric - (World System of Capitalism) Globalism and Regionalism. And in the late $20^{\text {th }}$ century U.S culture is penetrating the local and traditional Sino-Centric Order, but unfortunately, it is not last long, it is considered failed to be established in East Asia. Due to the globalization, rapid growth to information and technology and democratization it triggers the growth of post-modernism. Increasing global networking of nongovernmental bodies such as a multinational corporation, civil society organization emerge with horizontal networking among countries, shaping the triple structure "Tradition - modernity and PostModernity" and it is accepted and work in East Asia starting in the 21 $1^{\text {st }}$ century. (Rae, 2005).

Nowadays Hallyu boom is emerging triggered by modernized and industrialized East Asia whereas the people with economic power have the desire to be seen as a subject of their cultural activities rather than an object, they want to create something and get more profits rather than consuming. Korean wave could no longer be considered as simple cultural acculturation but more as a transcultural phenomenon more to "cultural power reorganization" through complex and dynamic essence of globalization such as people migration, mass media development, and transnational capitals. (Rae, 2005). Globalization always correlated with economic activity, as a market expansion which pushes the movement of human creativity in doing innovation in commodifying any form of products and goods, services including ideas. Movement and the development also the influence of globalization commonly pushed by some factors whichare not only economic factors itself but the factors that move the economic expansion in example massive industries, development of science, technology and communication (Lyman, 2000). The rise of Korean Popular culture is hand in hand with the essence of globalization free access, limitless society and liberation of information and mass media, somehow triggers more favorable environment to the new commodities and culture allowing interaction between nations to other nation which in return benefitted the spread of Korean Popular Culture.

Based on International Federation for Phonographic Industry (IFPI) in 2005 whereas the number of lost in music industries increasing due to the development of internet access and the birth of YouTube, Korean Music is still listed on the $30^{\text {th }}$ position as the largest music industries in the world based on its revenue. It is climbing to the $27^{\text {th }}$ position in $2007,14^{\text {th }}$ in $2009,11^{\text {th }}$ in 2012 , in 2014 Korean Music Industries listed at number $10^{\text {th }}$ of global music industries with the most rapid growth to $19,2 \%$ in a year, and in 2016 Korean music listed at number $8^{\text {th }}$ joining The US, England and Sweden as the largest country to export music in the world. (Jolin, 2017). The boom of Korean popular culture in all over Asian countries has increased and somehow penetrating the rest of other local culture over the past view years, this Korean wave somehow reached an active eruptions stage starting in 2000 to 2002 whereas it moves forward to rule all over Asia including Central and South East Asia. (Hyejung, 2007). The trend spread like a virus starting from Taiwan, Hong Kong, affecting all Chinese ethnic around Asia and Japan is positioned as the leader fan base of Korean Culture, not only music and drama but also film, fashion and food. The expansion of Korean Culture products has triggers curiosity around the world about Korean and its culture Korean Drama and Korean Music have served as the most significant pictures of Korea and as 
media to bridge other to Korea and this success of exporting culture has created a new facelift image of Korea in neighboring countries (Doobo, 2006).

Korean Music or K-Pop is becoming a phenomenon attracts many fans from all over the world, Globalization and new opportunity in foreign market present new challenges and problems especially in presenting commodities or products for Global customer. There are a lot of people claims to split "culture mission" from the concept of culture product which targeted Global Society. (Jolin, 2017). Could understand that the commodification of culture through transformation and adjustment toward the global needs will creates global acceptance and increasing consumers and creating massive profits.

\subsection{K-Pop and Commodification}

The force to do commodification of content is the main agenda for K-Pop in order to succeed in the world stage. Unfortunately, it is felt today that Korea is still too Alien for the rest of the world not only the culture, yet the language used, but it was not enough to stop the movement of this massive wave of culture to go global. What Mosco (2009) means by the commodification of content is the value edit, is to change particular values conveys by commodities and fills it with other values close enough to the target market follows the trend and the society demands to creates acceptance, wrapped it by global taste even local products. There was at least three reasons caused the big size of Korean wave; competences (Hard Power), attraction (soft Power) and criticism. (Sang-Bae, 2007). The success of the K-Pop music expansion toward the world also supported by the positive environment, in the ideas of Hard Power, KPop supported by the economic success of Korea through technology and automobile in the last $20^{\text {th }}$ century. In this part Korean wave considered as a symbol of Korean power which is considered as cultural-based technology indirectly force the creation of culture commodities. The Pan Asiatic Business has given so many profits to culture production presenting Korea as playmaker in marketing strategy through cooperation with the local in Asia and seeing Korean wave or K-Pop no logger as a culture but as commodities and also an industrial phenomenon.

The second idea over by Sang-Bae (2007) is attraction or the Soft Power, this attractiveness is necessary to stay the same and original keep the unique of Korean Wave and its culture. Whereas Korean wave or Hallyu is magical commodities contains the development of Korean style which not only has reach democratization but also economic acceleration an Authoritarian but harmony and dynamic in keeping the traditional values in the society. K-Pop attraction relies on the culture, it is never wrong when the Korean Government is in needs to supports this industry due to the positive effect on the tourism sectors in South Korea.

Based on the third Idea "Criticism" could bring success even only targeting the Asian markets but still under the cooperation with U.S-Led Global Cultural Order. The strongest power of K-Pop is never in High Culture but more too contemporary. Korean Traditional music somehow preserves but Korean commodification music, a music that got a touch of other nation like the U.S popular culture has grown rapidly. Music like RnB, Funk, Hip Hop also Pop rises above the ground and becoming so popular. Stars like Psy, Big Bang, Wonder Girls, Super Junior, 2Pm, Exo, BTS, iKon and also Black Pink is a result of this commodification of contains. This phenomenon gives understanding that "Korean Style "which is sensitive, creative and competitive developed even accepted through free markets, and also globalization. K-Pop music and culture is a new beacon of hope as East Asian Level Counter-Discourse in the midst of US-Led Global Cultural Hegemony in the Asian nations.

\subsection{K-Pop Change and Success}

The claims that K-Pop is a copy of Western culture is never been able to solve, K-Pop positioned from Drama, Serial, Films and also music is an example of how to interpret East Asia and Confucianism in the perspective of Korean (Rae, 2005). The existence of commodification clearly creates a change in certain values and add new values, it is useful to make a product that is accepted and sustainable in the midst of the society for gaining more profits, that the main reason of commodification which somehow could be a media of globalization or capitalism itself. This changing and transformation are somehow correlates with the ideas of "influence" it is not impossible that US-led Global Cultural Hegemony has influence and trying to penetrate the forming of East popular culture and creating new mix culture brought each identity or new identity of culture as the third group so-called hybrid. 
This new forming idea are not only for commercials matters as Thorsby (2005) stated before that the process of commodification has contributed to culture preservation to make culture not simply going extinct, but this commodification somehow has triggers wider range of commerce. The positive ideas about changing, transforming culture such as music are to show the identity of a nation in the world stage, to introduce the traditional and unique Eastern values or East Asian Values.

\section{Conclusions}

As a conclusion of this research is the success of music industries or K-Pop in its Global expansion is through three stages Competence or Hard Power, Attraction or Soft Power and last but not least Criticism. Like an actress in order to be able to continue or to have a sustainable career in global industries many things should be taken including "facelift". Globalization has triggered the popularity of K-Pop in the world. Globalization has a positive yet negative impact for those who can adjust and survive it could be a solution from the economic matters even in fighting against hegemony. This all could be achieved only by aware that everything could be changed and transformed into commodities and having values in the global market and create massive profits even it is considered a local product, as long as it is following and adjusting to the Global market demands and trend it will be profitable.

Three stages of K-Pop commodification are somehow becoming the answer for the Korean Government to preserve the country culture but yet justifying the commerce of culture. K-Pop Music becoming so dominant in the world stages today also as a result of competences that give an upgrade to their technology of communication and information and also automobile. Korean Government also focus on making soft power happen by creating images that Korea is attractive.

Last is Criticism that making away indirectly for more researchers to figure out Korea as a cultural phenomenon that somehow interesting to be studied. based on the International Federation for Phonographic Industry (IFPI) in 2005 Korean Music is still listed on the $30^{\text {th }}$ position as the largest music industries in the world based on its revenue. It is climbing to the $27^{\text {th }}$ position in $2007,14^{\text {th }}$ in $2009,11^{\text {th }}$ in 2012, in 2014 Korean Music Industries listed at number $10^{\text {th }}$ of global music industries with the most rapid growth to $19,2 \%$ in a year, and in 2016 Korean music listed at number $8^{\text {th }}$ joining The US, England and Sweden as the largest country to export music in the world and making Korea as one of dominating nation in exporting culture with the support of its government to make Music industries as commodities which later will support the other aspect and creates profits not only as commercial, but also a presentation of identity yet a powerful weapons against the war with West culture Hegemony.

\section{References}

1. Albrow, M. (1990). Introduction. In M. Albrow \& E. King (Eds.), Globalization, Knowledge, and Society: Readings from International Sociology (p. 9). London.

2. Baudrillard, J. (1981). For a Critique of the Political Economy of the Sign. St. Louis: Telos Press. p. 7

3. Berger, P.L. (2002). Introduction, in P.L. Berger \& S.P. Huntington (Eds.), Many Globalizations, pp. 1-16. Many Globalizations: Cultural Diversity in the Contemporary World, Oxford University Press, Oxford.

4. Bourdieu, P., \& Thompson, J. B. (1991). Language and Symbolic Power. Cambridge, USA: Harvard University Press.

5. Dunn, R. G. (2008). Culturalizing consumption. In Dunn, R. G. (Ed.), Identifying consumption: Subjects and objects in consumer society (pp. 51-77). Philadelphia, USA: Temple University Press.

6. Doobo, S. (2006). "Hybridity and the rise of Korean popular culture in Asia." Media, Culture \& Society, 28(1), 25-44. doi:10.1177/0163443706059278

7. Giddens, A. (1990). The Consequences of Modernity. Cambridge: Polity Press.

8. Hyejung, J. (2007). The Nature of Nationalism in the "Korean Wave": A Framing Analysis of News Coverage about Korean Pop Culture. Conference Papers -- National Communication Association, 1. Retrieved from Communication \& Mass Media Complete database. 
http://citation.allacademic.com/meta/p187925_index.html. (accessed on 26th September 2018).

9. Jolin, J.W (2017) The South Korean Music Industry; The Rise and Success of K-pop. Stockholm.2017 Stockholm University. Department of Asian, Middle Eastern and Turkish Studies.

10. Kraidy, Marwan. M. (2005) Hybridity without Guarantees: Toward Critical Transculturalism. Hybridity, or the Cultural Logic of Globalization. Temple University Press. Retrieved from https://www.jstor.org/stable/j.ctt1bw1k8m.11. (Accessed on 25th September 2018).

11. Lyman, P.N. (2000) Globalization and the Demands of Governance. Georgetown Journal of International Affairs (Winter/Spring). Premier Issue.

12. Mason, J. (2002) Qualitative Researching second edition. London. Sage Publication

13. Mosco, V. (2009) Political Economy of Communication. London. Sage Publication.

14. Proschel, N.Commodification and Culture How can culture be economically used without selling it out?. Retrieved https://www.modul.ac.at/uploads/files/Theses/Bachelor/Thesis2012-Proeschel-Natascha.pdf $+\& c d=1 \& h l=e n \& c t=c l n k \& g l=i d$. (Accessed on $25^{\text {th }}$ September 2018).

15. Rae, K. B. (2015). Past, Present and Future of Hallyu (Korean Wave). American International Journal of Contemporary Research. Vol. 5, No. 5; October 2015.

16. Robinson, W. I. (1998). 'Beyond Nation-State Paradigms: Globalization, Sociology, and the Challenge of Transnational Studies,' Sociological Forum, Vol. 13, No. 4 (Dec., 1998), pp. 561594. Retrieved from https://www.jstor.org/stable/684864 (Accessed on 27 $7^{\text {th }}$ September 2018).

17. Sang-bae, Kim (in Korean) (2007) "The Attractiveness of Hallyu and East Asian Cultural Network," Journal of World Politics, the 28th Series, n.1, pp. 208-212.

18. Tomlinson, J. (2000) Globalization and Culture. Cambridge. Polity Press.

19. Throsby, D. (2005). On the sustainability of cultural capital. (Research paper, Macquarie University, Sydney, Australia).

20. Waters, M. (1995) Globalization. 2nd Edition. London. Taylor and Francis Group 